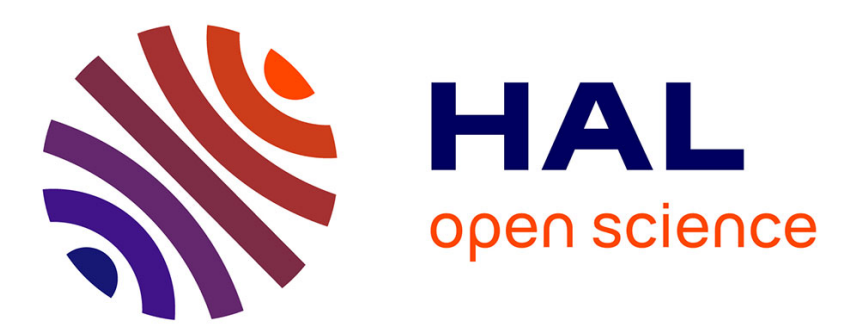

\title{
Pro-environmental strategies in search of an actor: a strategic environmental management perspective on environmental NGOs
}

\author{
Laurent Mermet
}

\section{- To cite this version:}

Laurent Mermet. Pro-environmental strategies in search of an actor: a strategic environmental management perspective on environmental NGOs. Environmental Politics, 2018, Environmental NGOs at a crossroads, 27 (6), pp.1146-1165. 10.1080/09644016.2018.1482841 . hal-02892853

\section{HAL Id: hal-02892853}

https://hal-agroparistech.archives-ouvertes.fr/hal-02892853

Submitted on 7 Jul 2020

HAL is a multi-disciplinary open access archive for the deposit and dissemination of scientific research documents, whether they are published or not. The documents may come from teaching and research institutions in France or abroad, or from public or private research centers.
L'archive ouverte pluridisciplinaire HAL, est destinée au dépôt et à la diffusion de documents scientifiques de niveau recherche, publiés ou non, émanant des établissements d'enseignement et de recherche français ou étrangers, des laboratoires publics ou privés. 


\title{
Pro-environmental strategies in search of an actor: a strategic environmental management perspective on environmental NGOs
}

\author{
Laurent Mermet
}

Département Homme et Environnement, CESCO, Museum National d'Histoire Naturelle, Paris, France; Département Sciences Economiques, Sociales et de Gestion, AgroParisTech, Paris, France

\section{Introduction}

Leaders of environmental NGOs (ENGOs) accept a dual challenge. They have an organisation to manage and they have to carry out actions addressing environmental issues in the face of considerable inertia if not outright resistance (Rowell 1996). They have to design, implement and revise a strategy, not just a plan to coordinate action but, as Richard Rumelt (2011) insists, a statement that clearly identifies the few crucial challenges the organisation faces and that articulates a cohesive response to them, a statement that will guide all decisions at all levels of the organisation. A well worked-out strategy is 'a coherent set of analyses, concepts, policies, arguments, and actions that respond to a high-stakes challenge' (Rumelt 2011, p. 7).

On a different level, as an academic discipline strategy is part of management. It rests on the necessity of combining subjective and objective data and analyses, and of organising the collaboration of practical and theoretical thinking to produce academic work that can guide both the analysis and the design of organisations' strategies (Mintzberg et al. 1998).

Our purpose here is to draw from management, and especially from developments in strategic analysis of environmental management, to shed light on the strategic challenges that ENGOs face today. NGOs are not just collective political actors but also organisations that have to be managed if they are to be effective. Real-life action of ENGOs depends not only on principles, goals and political stances, but also on human resources, financial means, organisational tools and routines, and coordination. For large ENGOs, the strategic management challenge is considerable because they have great needs in coordination, planning, budgets, and because mistakes can have damaging consequences. For small ENGOs the challenge may be different in content and form, and the stakes may seem lower, but it is just as steep since the means are limited.

Overall, management as a discipline can and ought to be bettermobilised to analyse and support the ways in which ENGOs manage their operations. This, however, is not simply a matter of mobilising concepts and approaches that have been developed for businesses or government organisations and 
applying them directly to ENGOs, which can and should be done only for such aspects of ENGOs' strategies as are similar to those of firms or public agencies: managing budgets and finances, staff, public image. But there are fundamental differences that affect the core of ENGOs' strategy.

To identify them, one can start from the dual challenge underlined above: ENGO leaders have both to strategically manage an organisation and to strategise for effective intervention to address specific environmental issues.

Regarding the management of the organisation itself, some of the general traits of NGOs are associated with their not-for-profit character, their legal statutes, and their sources of income (Crowley and Ryan 2013). More specific and fundamental features of ENGOs stem from their central raison d'être and mission: acting to promote an environmental cause.

Guillet and Leroy (2010) point to the second challenge for ENGOs: how to design and implement strategies for decisive interventions on environmental issues? This is a different sphere of strategy and action, played out largely in public arenas, with a specific vocabulary and grammar of action: mobilisation, advocacy, demonstrations, lobbying, coalitions, pressure, public opinion, public policy, awareness-raising, empowerment. Here also concepts and approaches from management, and especially from strategy, can be enlightening. They need, however, to be adapted to be relevant to the strategic analysis not of managing one organisation, but of managing a system of organised action, and to fit the specificities of the collective management of environmental issues.

This has been the main reason for developing the strategic environmental management analysis approach (SEMA) (Mermet 2011, Mermet and Leménager 2015), a strategic management approach that proposes a conceptual framework and adapted action research methods to address the quest for effective collective action strategies to resolve environmental problems. It follows the lead of Crozier and Friedberg (1980) in adopting a wide view of organisation that encompasses not only fully institutionalised organisations such as one firm, NGO, or public agency, but also organised action beyond such organisations, and embraces the dual meaning of 'organisation' - both the process of organising and the result of that process (Hatch 1997).

The two faces of ENGOs' strategic challenge - running an organisation and deploying effective organised action in the public arenas of environmental issues - are deeply connected, as the means of the organisation are instrumental for the definition and success of public action, and the ENGO's part in organised public action affects in turn its functioning and means (Guillet et al. 2016). Decisive action to resolve specific environmental issues should be central in strategic analysis of ENGO management since it is the core of their defining mission as organisations.

Here we present and discuss how SEMA can shed light on this shared key to the internal and external management of ENGOs so as to guide strategic thinking for ENGOs and reframe some of 
the major difficulties ENGOs now face. We start by introducing some basic elements of strategic reasoning for ENGOs: the strategic nexus that links together each ENGO's identity, goals, resources, strategies and opponents; the way strategic reasoning differs depending on which point of the strategic nexus one starts from (what strategy for organisation $\mathrm{O}$ ? or what kind of organisation is needed to carry out strategy S?). Each of the three following sections then develops one theme of SEMA research that seems particularly relevant to guide the analysis of ENGOs' strategic challenges: the key role of opponents and of (overt or covert) confrontation in environmental strategies and the difficulty of addressing them adequately in a time still dominated by sustainable development, win-win, collaboration and co-construction approaches; the necessity of overcoming the frequent fuzziness about identifying which actors really want a given environmental problem to be solved, and on whom effective environmental strategy actually rests, in a context where most environmental problems are presented as being everybody's problem, but often appear to be a priority for few; the often overlooked importance of activity sectors (e.g. farming, transport, energy), including the environmental sector as the lasting, large-scale interorganisational organised action structure within which ENGOs operate and wherein lie their most important structural alliances. Finally, we turn to a crucial aspect of strategic reasoning: the difference between strategic thinking in ex post research (reconstructing strategy after the fact) and in ex ante research (analysing strategic challenges before the act). Considering that difference is important to allow dialogue between disciplines covering ENGOs' strategy from different perspectives, and between researchers and practitioners of ENGO strategy.

\section{Strategic reasoning: the nexus of identity, aims, resources, strategy and opponents}

(Mintzberg et al. 2003, p. 10) define strategy as:

The scheme or the plan that integrates into a coherent whole the organisation's main goals, its guiding policies, and its action programs. A well formulated strategy allows to order and allocate the organisation's resources on the basis of a viable and unitary position, grounded in its internal capacities and weaknesses, of anticipated changes in the organisation's environment, on contingent measures taken by intelligent opponents [to make the organization's action fail].

This definition does not focus so much on the form of the strategy (e.g. a formal official action plan or a motto, a mission statement) or on the process to define it (e.g. an inclusive internal 
participatory process, or an advisory study by consultants) as on its content: a practicable theory of action about how to address the main challenges the organisation has to overcome. Strategic reasoning articulates the organisation's main challenges and goals, its resources, identity, opponents or competitors, policy and actions, so as to provide a central, generative formula for the organisation's action in general, and a template and referent for its more detailed action plans (Rumelt 2011).

But where does that reasoning start? Let us take the example of a successful campaigning ENGO such as Greenpeace, which has a well established mode of action: loud campaigning targeted directly at the general public so as to exercise pressure on public authorities and economic actors. Its resources, i.e. the kind of staff it employs, the structure of its organisation, the way it links budgetary resources and expenses around the campaign themes it pushes at a given time, have been fine tuned over time to be well adapted to that mode of action. Choosing a strategy based on another mode of action (for instance, on expert-studies-based soft lobbying of public authorities, or collaboration with grassroots communities in solving their problems) would require very deep change. In England, Friends of the Earth has attempted to do both, Greenpeace only rarely the latter (Rootes 2013). Thus their strategic reasoning at a given juncture is likely to take for granted their organisation's identity, structure, resources and, starting from there, to look at the choice of campaigning themes that would use these resources most efficiently and effectively. In return, a good choice of campaigning themes will increase their fundability, enhance their public image, and reinforce their identity and resources.

This line of reasoning - from the organisation and its most efficient mode of action, to the resources it has available, to the opportunities that it is well equipped to take up - is familiar to other kinds of organisations but it is only one of the ways in which the dots of the strategic nexus can be linked to one another.

In the late 1980s, the French government proposed a plan to build four dams on the Loire River, essentially for irrigation and flood control. ENGOs (as well as theMinistry of the Environment) objected to the plan because of its questionable benefits and unacceptable environmental impacts on a great river ecosystem. But if they were to halt the dams, they would have to find a strategy. Here, strategic reasoning started from a given environmental issue, and had to move from there to the modes of action that might succeed in stopping the project, and from there to the kind of organisation that could successfully initiate and carry out such actions. With the advice of an activist who had just taken part in the successful struggle against a dam project on the Danube in Austria, the handful of NGO staff and members who mobilised to take up the challenge of stopping the Loire dams defined a strategy combining media and general public campaigning, militant 
occupation of one dam site, and mobilisation in public policy arenas of academics and experts to undermine the technical and economic rationale of the project. No one NGO had the skills and resources to carry out such a strategy, so a new organisation had to be formed. WWF and other NGOs, including local ones, created 'Loire vivante', a 'coordination', an ad hoc, temporary organisation, to take up the challenge of stopping the projects, which it essentially accomplished when the authorities abandoned three of the projected dams after a struggle that lasted several years. We have a different line of reasoning here: one that starts from a given environmental goal (or problem), looks for possible effective actions combined in a relevant strategy and, from there, proceeds to define an organisation that will focus on that environmental goal and carry out the strategy. Since the identity of an organisation, its resources, possible modes of action, and goals define one another in a circular way, strategic reasoning has to choose where to start. (Watzlawick and Beavin et al. 1967) call this choice 'punctuation', starting from one or another of the elements of a circular logical chain and exploring from there the links between them. They underline that several choices of punctuation can be relevant, even though each will create a very different view of the problem and solutions.

The line of strategic reasoning that starts from an environmental problem to solve, an environmental goal to be reached, or an ecosystem to be better managed, seems particularly relevant for ENGOs because it starts from the very mission that inspires their existence: for an ENGO, there is no justification for its existence, or basis for evaluating its action, other than the environmental mission upon which it is founded.

\section{Strategic environmental management analysis: beyond policy-centred approaches}

This line of reasoning - from a given environmental problem to the possible actions that might solve it to the actors that could carry out such actions-is the basis for strategic environmental management analysis (SEMA) (Mermet 1992, 2011). With one foot in strategic management and one in environmental studies, it has transferred strategic management reasoning to environmental management situations that differ from the company or public organisation management issues usually addressed by management as a discipline. It has combined conceptual work to transpose or transform strategic management theory for that use, and field cases in various forms of action research (with the researcher being involved in the management efforts s/he studies) also inspired by strategic management methodologies (David 2000). Applications include especially the diagnostic of complex environmental management situations (Emerit 2007, Taravella 2008), the strategic critical assessment of current environmental management discourse and doctrine (Billé 
2008, Leroy and Mermet 2014), policy evaluation (Mermet et al. 2010, Leroy and Mermet 2012), and strategic analysis for organisations whose mission is to get environmental problems solved, in particular ENGOs (Guillet 2011, Guillet and Leménager 2016).

Treating environmental problems such as deforestation, coastal ecosystems degradation or wetland destruction as management problems may seem unusual. More often, they are framed as environmental policy problems. For instance, mangroves are disappearing at an alarming rate: what public policy can be put in place to identify and address mangrove degradation? This familiar line of reasoning is underpinned by an implicit definition of the problem as one of moving from an unmanaged situation to one that is managed through public policy. From a strategic environmental management analysis perspective, however, such problems do not correspond to unmanaged situations, but to management systems that deliver bad results from an environmental evaluation standpoint. A mangrove that shrinks due to the development of shrimp farming, tourist resort development and villagers' excessive wood extraction is very much managed by planners, village authorities, traditional users and shrimp companies. There is lack of neither organisation nor management strategy. The problem is rather that they deliver poor performance if considered from the specific viewpoint of those stakeholders who focus on mangrove conservation. A large, prosperous corporation that lets go a fourth of its workforce, shrinks the pay of the rest and becomes even more prosperous is not unmanaged; it is actively managed in a way that delivers poor performance, if examined from a social perspective.

SEMA reframes environmental management problems by starting from a clearly defined environmental concern, thus separating the actual management of that concern (the action system that determines performance, in this case, the environmental outcome) and intentional environmental management (the action system that strives to obtain satisfactory environmental performance). Environmental outcomes are neither the result of an absence of management nor the result of environmental policy; they are the result of the dialectics between the action system that manages them de facto, and the action system that intends to get better environmental outcomes ${ }^{1}$.

One effect of this reframing is that it pulls away from public authorities the main role in managing environmental problems. Inmost cases, the initiative does not initially come from them (but rather from scientists, grassroots activists, journalists, civil society organisations), and public authorities rarely act alone to solve an environmental problem. It also underlines the fact that public authorities and public policy are on the side both of the problem and of the solution. For instance, they are both at the heart of an agricultural policy that supports farming systems and land management that

1 An action system is a set of actions, actors, rules, stakes, objects, that are interrelated and play out in ways that generate emerging dynamics and outcomes that may go beyond or contradict the results of each action taken in isolation (Watzlawick et al. 1974, Checkland 1990). 
deplete farmland bird populations, and the operators of biodiversity strategies that prioritise the conservation of farmland birds (Gamero et al. 2016). They have split purposes and are departmentalised not by accident but by construction, and this should be taken not as a perplexing mistake, but as a fundamental organisational reality for environmental strategies. Public authorities and public policies are both too narrow (other operators are just as important) and too wide (they also pursue contradictory objectives to a large extent) to provide the basis for a sound strategic analysis of action in favour of the environment.

To extricate our understanding from the hegemony of public policycentred approaches to environmental issues, SEMA has developed a set of core concepts that delineate an alternative perspective based not on the standing of operators (e.g. public policy versus private interests), but on where actors really stand with respect to environmental goals and action. We shall now present and discuss three such concepts that shed light on the strategic issues that ENGOs currently face: the omnipresence of cooperation-oriented discourse; the pressure of sectoral interests; the rapidly changing context and difficulties of forming pro-environmental coalitions. The final discussion returns to the more general level of strategic reasoning for ENGOs and the consequences for research.

\section{Strategic confrontations that disturb in a context dominated by cooperative ideas...}

A first contribution of a strategic perspective is that it allows - and demands - a clear treatment of the adversarial and divisive dimension of environmental management, and of ENGOs' strategies. Reaching a given environmental goal (e.g. halting water pollution, reversing the collapse of pollinator populations, restoring healthy ecosystem functions in a river) is in many cases problematic because it conflicts with other goals, interests and policies. Reaching the goal in such cases requires winning for the environment in some form of struggle between, on the one hand, actors who prioritise the environmental goal and, on the other, actors who don't. The succession of confrontation, public advocacy, lawsuits, committee debates and negotiations that are part ofmost environmental management processes requires those actors that clearly act in favour of reaching the environmental goal to overcome inertia, resistance or backlash from other actors. This requires strategy not just in the bland sense of a coordinated plan of action (Mintzberg, 1994), but also in the stronger sense of action capable of overcoming deliberate opposition-'contingent moves by intelligent opponents'. In other words, any strategy in favour of the environment - and thus the strategies of ENGOs - crucially involves dealing with adversaries who (whatever their public 
discourse) are not ready to do (or let others do) what it takes to reach the environmental goal and are apt to oppose environmental action accordingly.

Recognising this adversarial dimension, diagnosing it carefully in each situation where an NGO has to intervene, is nothing new for those who carry out environmental action: overcoming resistance to environmentally motivated change is at the heart of their experience. It was also quite straightforward for academics several decades ago, when environmental claims often confronted explicit, frontal resistance fromeconomic and other interests. In times of sustainable development goals, win-win strategies, co-construction of solutions, roundtable management mechanisms, integrated management, agro-ecology, openly discussing that dimension can become highly problematic, for two quite different, but converging reasons.

The first is peer pressure within academic fields dominated by researchers advocating collaborationbased solutions to environmental challenges. That pressure is made more acute by the argument that there would be a selffulfilling character to analysis that underlines the cooperative or adversarial nature of environmental management situations; if one points to the adversarial dimension, one is accused of activating that dimension, of aggravating environmental conflicts, and thus of blocking their (conflict-resolution-based) solution. The second is intrinsic to the logic of strategic thinking, which involves discussing ways to overcome competition or opposition. Holding such discussions in view of one's competitors or opponents is self-defeating because many strategies become much less effective if opponents are aware of them. In a context dominated by collaborative principles and collaborative management concepts (as the environmental field has been since the early 1990s (Mermet 2011)), both these difficulties converge. Adversarial strategising (from both opponents and supporters of environmentally motivated change) is conducted under a blanket of cooperative discourse and process, and of ethical and social concerns that make explicit strategic analysis on environmental issues NGOs especially difficult.

The difficulties experienced by ENGOs criticising high-environmentalimpact projects in Indigenous lands (Pickerill 2018) illustrate this. Such projects may be backed by an alliance of Indigenous groups and large, highenvironmental-impact companies. If criticised on environmental grounds, the alliance can counterattack from ethical high ground by claiming that ENGOs are attacking Indigenous rights and disadvantaged groups. Similarly constrained are ENGOs' actions against the devastating impact of intensive agro-chemical agriculture on France's biodiversity. The agricultural sector is so cohesive that it is not possible to criticise it effectively without confronting farmers but farmers are regularly represented in the media as victims of economic crises, making it is very difficult for ENGOs strategically to squarely confront them. ENGOs tend as a result to be stuck between attacks on a limited group of actors with a bad public image (e.g. Monsanto-bashing), or 
adopting cooperative language with other actors who may have no actual intention to cooperate. In such cases, the seemingly ethical (and actually strategic) pressure to conflate all good causes and to collaborate rather than confront leads to highly restricted, clumsy and biased strategic diagnoses and discussion in the media and in public debate, but also in academic forums.

Dealing with opposition is an essential not an optional part of proenvironmental strategies. Over the last two decades, opponents, their discourse, alliances and strategies, as well as the context in which the confrontation occurs, have changed in ways that require that ENGOs reexamine the adversarial dimensions of their strategies.

But at the same time, these very same changes make that exercise especially difficult. One of the first necessary steps is to create a 'safe-space' where ENGOs, analysts and researchers who share their aims can freely discuss the strategic difficulties at hand. Creating such a safe space is made difficult by project management situations that incentivise a display of success and make the discussion of failures — and thus realistic learning — difficult (Redford and Taber 2000). A safe space for strategic discussions for ENGOs is also one in which their (overt or covert) opponents cannot participate so that the adversarial dimension can be safely analysed.

This is made more difficult in a context dominated by multi-stakeholders roundtables and the 'participation imperative', but is nevertheless a necessary step for ENGOs. Furthermore, such safe spaces require that opponents cannot overhear or be informed by the discussions. This creates a special challenge for researchers, whose analyses are usually recognised only if they are published, and thus made available to all, which creates a problem for strategic thinking, and an incentive to restrict it to collaborative principles and solutions (Raiffa 1982).

\section{... and that define environmental actors}

The idea that solving an environmental problem relies on a strategy for change against inertia and resistance implies that environmental action requires the existence of an actor to define and perform this strategy, facing other actors who passively or actively resist (environmentally motivated) change. In SEMA, this actor is by definition the environmental actor, a concept that involves a critique of the many diverse prescriptions about environmental action that rely on fuzzy agency and address their prescriptions to some vaguely defined collective: 'we', 'the country' 'the stakeholders' or 'humanity'.

The environmental actor is a concept that derives from strategic reasoning that starts from the environmental problem, looks for the action system that causes the problem, then for the strategies 
that may change that system, and finally for the actor that may have the will and means to carry out such a strategy, even in the face of other inert or resistant actors.

In field case studies this implies that the analyst has to investigate and identify in detail, in each situation, who is effectively acting to reach the environmental goals that serve as a reference for the case analysis. This approach is very different from one that observes what actors are present in the situation, and then studies their intents and actions. It identifies actions that should be carried out to resolve a problem and questions the existence, purposes and capacities of the actors on the ground. In his study of deforestation in the Amazon, Romain Taravella (2008) found that the organised system of deforesting for cattle raising is so dominant that the researcher had to move to another town to find NGOs that actively struggle against it; the level of threat and actual violence against them was such that they did not appear on the same scene, socially and geographically. In that case, the environmental actor is a coalition of social and environmental NGOs, a 'coalition-based environmental-actor' (Taravella 2008). On brown bear conservation in the Pyrénées, a loose network of actors (two or three ENGOs, a few civil servants in the national and regional offices of the Ministry of Environment, a few experts and academics) carried the burden of action against massive resistance, including from institutions that displayed brown bear protection as their aim, but were in effect resisting bear conservation and defending farming and forestry interests (Benhammou and Mermet 2003).

Identifying who carries the strategies to effectively resolve a given environmental problem is almost never straightforward. It requires critical field investigation, and the result often points to the limitations and organisational difficulties of the actors on whom environmental strategy has to rely. In some situations, as in Maya Leroy's study of the management of the Senegal valley ecosystem (Leroy 2006), field investigations have (disconcertingly at first) failed to find anyone on the ground who was seriously invested in carrying out conservation strategies, despite the high visibility of conservation goals and the complex conservation mechanisms in place at the national and international levels The existence of an environmental actor (however badly needed) is not a given, and any strategy for conservation in the field will be limited by the actual existence and capability of an actor to carry it out - an important part of the strategic realism promoted by SEMA. The concept of environmental actor and the kind of analysis it entails go against the grain of much contemporary environmental studies work that focuses on instruments, or on institutions. By doing so, it can be enlightening for ENGOs in several ways.

First, it can support an effort to re-establish the importance and legitimacy of ENGOs, at a time when they are threatened by de-differentiation in public scenes where almost all actors present themselves as champions of the environment (Guillet and Leménager 2016). Careful screening of 
actors, as they reveal by their actions which side they are on in struggles about an environmental problem, may in many cases relocate an NGO as a crucial member of a pro-environment network that is hard pressed by the challenges it has to overcome, rather than as a mere member of a crowd of actors adopting similar environmental discourse.

A second use of the environmental actor concept is as the basis for building a referent when evaluating an ENGO's action. As shown by Fanny Guillet's (2011) action-research-based study of Tour du Valat (TdV), strategic planning and evaluation for an ENGO can benefit from systematically looking at the organisation's goals, resources and actions in relation to an analysis of what the environmental problem demands in terms of strategic action. In that case, it is striking to see how funders, NGO staff, and other environmentally-motivated stakeholders expect strategies and evaluations that reach beyond the organisation evaluating itself on its own terms, and strive to put the organisation's actions in light of the very strategic - sometimes daunting - challenge of conserving Mediterranean wetlands, which is the raison d'être of TdV. Even though the strategic planning and evaluation procedures address the internal needs of the organisation, they follow the line of reasoning that starts from the environmental problem to be resolved, and only then move to the organisation's goals and activities: what kind of actions and actors would it take to achieve conservation of Mediterranean wetlands?; to what extent does TdV measure up to the demands of that hypothetical mobilisation?

A third contribution of the 'environmental actor' concept rests on the fact that in most situations, adequate environmental strategy has to combine forces of several organisations that together operate as the environmental actor, whether by a formal organisational link - a coalition, alliance or organised network - or more covertly, or tacitly, as when a strident campaigning NGO provides leverage for a quieter NGO to negotiate more favourable policy with authorities, or of civil servants discreetly feeding an NGO with information to help its members lobby for a policy that the civil servants themselves struggle to advance through internal channels. In most cases, successful environmental action rests on a fragile, changing synergy of pro-environmental actors that operate in a loosely coordinated way. Reflecting on the composition, condition and evolution of the set of pro-environmental actors with which it needs to synergise to be successful is a crucial component of an ENGO's strategic reasoning, starting from the demands of a situation, and moving from there to examine who exactly is ready to mobilise on the ground.

\section{The scale of action for change: locating ENGOs in the environmental sector}


Analysing the strategy of an $\mathrm{NGO}$, or accompanying its leaders in strategy design, requires understanding its links to other actors who may operate in synergy with it to attain shared environmental goals. On what scale should one analyse these links: in terms of their durability and stability; the breadth of their goals; the scope of the participants to be included? Are we discussing ad hoc coalitions limited to a comparatively narrow issue for the limited time of one decisionmaking process? Or are we envisaging stable, structured synergies that deploy over decades, cover a wide range of related issues and activities, and involve a large variety of actors with convergent goals, but very different means and institutional standing?

The concept of the environmental actor fits at the first, small-scale end of that continuum: it starts from one environmental problem, and investigates what set of actors proactively acts to resolve it. At the large-scale end of that continuum, strategic environmental management analysis places great importance on activity sectors and considers them key to understanding the organisational and strategic dimensions of environmental management. To show their importance to ENGO strategies, let us start with productive sectors and then turn to the environmental sector itself.

If one presses a farmer to change practices that generate water pollution or biodiversity loss, it usually becomes apparent that these are very difficult to change on an individual basis. The farmer's choices are part of a wider organised system of activity that includes the industry's technical support chain, trading organisation and market conditions, the training and culture of farming organisations and unions, all of which are backed up by regulations and incentives enforced by the agricultural administration. The farming sector thus functions as a large, functionally highly coordinated organisation for collective action, in which technical, economic, educational, legal and administrative components share essential concerns and actively coordinate their actions and strategies. This sector-based organisation of productive (or service) activities that impact the environment is a crucial consideration in analysing and designing ENGOs' strategies as they press to change behaviour and production systems.

But it is important as well to consider how environmental actors rely on their own, environmental sector. We define a sector as a large scale interorganisational action system purposefully put in place to cover a set of related needs, through the production of goods, the provision of services or the exercise of vigilance and intervention. Each sector involves organisations with very different roles and institutional standing: private firms, unions, professional associations, administrative departments, research institutes, specialised schools and universities, specialised media, event organisers. These organisations are linked and interdependent in multiple ways: students from specialised schools become interns in companies or administrations, and then become staff; research institutes collaborate with other organisations of their sector; staff move from one type of 
organisation to another; an administrative organisation controls firms that in turn influence regulation, in synergy with the pressure of unions and professional associations, with specialist consultants called in to advise. Sectors build and retain their organisation over the long term (enduring institutions, and intergenerational transmission of missions, values and skills). Each is built around a wide but well identified portfolio of needs that the sector serves, and that justify the sector's lasting, large-scale organisation to produce the goods, services, or vigilance that serve that set of needs.

Over recent decades, environmental management and policy have been gradually institutionalised, organised and scaled up to become a full-fledged sector, with its ministries, agencies, specialised firms, research and higher education institutions, and NGOs. As soon as one starts to reflect on the strategy of an ENGO, the decisive importance of its being embedded in the environmental sector becomes apparent: what access does the NGO have to officials in environmental public service organisations? Can it collaborate with researchers who share similar environmental concerns? With what other NGOs with similar missions can it ally, or does it compete? What interpersonal relationships can be used between the NGO staff and staff from other types of environmental sector organisations, who share the values and technical culture of the environmental sector?

A clear vision of the sector where an ENGO is embedded is essential because the roles played by organisations in the environmental sector are complementary, vary according to place, and evolve over time. From one country to another, the respective roles played by the State, the private sector, and NGOs may be very different; each NGO has to define its strategy in view of the particular (formal and informal) distribution of roles in the environmental sector of the country (or district) in which it operates. The situation in that respect also changes over time, as the environmental sector as a whole becomes stronger or weaker under the pressure of public opinion, economic changes and political decisions, and also as organisations within the sector see their roles and influence shrink or expand.

As a result of this tight interdependence of ENGOs with the environmental sector of which they are part, analysing the situation of the environmental sector, its changes and perspectives, is key to reflecting on the strategies of ENGOs. For example, the French tradition and institutional system impart a leading role to the State, and NGOs have a much lesser role, fewer resources and more restricted margins of manoeuvre than they do in other developed countries such as the UK or US. In 2007, President Nicolas Sarkozy organised the 'Grenelle de l'Environnement', a highly publicised national roundtable to boost environmental policy. This event and its conclusions polarised the attention of the public and the environmental sector for several years afterwards (Boy et al. 2012). The roundtable and its sequels conferred a higher level of visibility and influence on ENGOs. 
However, at the same time the government quietly introduced farreaching changes that affected the entire environmental sector, merging the Ministry of the environment into the (much larger) Ministry of public works, housing and transportation, at both national and local levels, also including the Ministry of agriculture in the merger of regional administrative services. Over time, these changes dramatically decreased the capacity of officials to independently defend environmental issues that involved confronting public works, urbanisation, transportation or agricultural interests. This and other policy changes also led to an important decrease in the administration's subsidies to ENGOs, which reduced their already comparatively limited resources (Berny 2019). As a result, although the Grenelle de l'environnement seemed at first to enhance the standing and influence of French ENGOs, over the longer run it degraded their strategic situation by weakening their allies in the administration and depleting their financial resources. In short, given the tight interdependence of ENGOs with the structure, functioning and transformations of the environmental sector as a whole, the state and evolution of the latter is an essential basis for the analysis of ENGO strategy.

We use here the sector - or to be more explicit, the activity-sector as the organisational concept to describe the inter-organisational arrangement in which each ENGO is embedded, because we consider it to be both more inclusive and more relevant to strategic analysis than some other concepts often used when discussing these issues. The concept of 'advocacy coalition' (Sabatier and Jenkins-Smith 1993) proposes an analysis of the wider organisational inclusion of NGOs based on one activity (participating in the decision-making process about public policy), on a restricted set of issues, and on the idea of a coalition. The variants of policy networks (Thatcher 1998), are also based on decision-making about policy as the main activity, but on an issue defined more widely, and more persistent; whereas a coalition involves actors with heterogeneous goals joining forces in an ad hoc way, most forms of policy networks tend to group organisations and people who share the same broad priorities. By contrast, in management theory, the concept of 'industry' refers to the set of organisations (especially businesses) that provide a certain type of good or service (the auto industry, the food industry). One could by analogy name 'environmental industry' the set of organisations that participate in environmental protection and restoration, vigilance, education, research and lobbying. Here the focus is on activities other than making decisions about policy.

Activity sector is here conceived as the main meta-organisational grouping for strategic analysis, because it does not artificially separate policyrelated and activity-based organised action. It is the same farming sector that organises its industry to deliver agricultural produce and that lobbies for policies that support its organisation of production. The interest of not separating organising for activity and for policy influence may seem less obvious for the environmental sector, which is not 
centred on production. Nevertheless, it is the same environmental sector organisations that conduct research in ecology or water pollution, provide consultancy to firms on their environmental impacts, train students and educate the public, and lobby in favour of more aggressive environmental policies.

The strategies of these organisations have to combine all these types of activities so that reflection on their strategies is best served by analysis of meta-organisational inter-dependencies that does not separate them. Finally, we note that 'sector' is often used in variable ways: it sometimes designates organisations with similar standing - the private sector, the public sector, the non-profit sector, or with similar standing and similar objectives; thus Armsworth et al. (2012) mention the 'conservation-non profit sector'. Such uses miss the main point of the 'activity sector' whose importance we underline here: the (formally and informally) organised, long-term interdependence between all the organisations that share the same large-scale mission.

\section{Studying strategy ex post or ex ante?}

Strategic concepts and reasoning from management in general, and from strategic environmental management analysis in particular, can usefully contribute to the reflections of both researchers and practitioners about ENGO strategy. There is still a need, however, to discuss how such concepts and strategic reasoning relate to, and differ from, analyses of NGO strategies grounded in other disciplinary backgrounds, or from other streams of management that do not share the research-anddesign perspective we have adopted. This discussion can be introduced through the distinction between three perspectives on strategy (Mintzberg et al. 1998): strategy as deliberate design (the organisation's leaders assess the situation, design options and choose one as a strategy); strategy as process (an observer closely follows the leaders and members of the organisation as they interact in negotiation and decision-making processes that lead to the strategic options and actual behaviour of the organisation); or strategy as emergent (an external observer distances himself from the organisation and examines what actual strategic behaviour the organisation has displayed, without reference to its discourse and intentions).

The latter perspective, mostly represented by studies that use statistical methods to compare the performance of organisations in the same industry, is illustrated by Paul Armsworth et al. (2012) who compare the performance of 1700 conservation NGOs according to size. It is of lesser concern to us here, because it is less related than the other two to the pragmatic situations and perspectives of NGO managers, and thus to reflections that can be conducted jointly by researchers and NGO managers. 
Strategy as process is very influential in current management research, as illustrated by 'strategy as practice', a very dynamic stream that has developed over the last two decades (Whittington 2007). This perspective corresponds to the 'pragmatic' turn in social science (Dosse 1998), of which Nathalie Berny's recent book (Berny 2019) shows the relevance for in-depth analysis of ENGO strategies. It also reflects the perspective of most research in history, as it takes care to understand the situation and subjective perspective of the actors (Ricoeur 1990) - which is quite apparent in Berny's book and in other research adopting a historical perspective on ENGO strategy. Amajor characteristic of such research is that, to paraphrase Bruno Latour (2007), it follows the actors, closely and carefully, just one step behind as it were, so as to account in detail for how they understand each situation, what they do, and for what reasons.

By contrast, the strategy-as-design perspective (David et al. 2000) accompanies and supports the actors, also walking alongside them, but one step ahead, rather than one step behind. It rests on an on-going thought experiment based on the question: 'if one were in this situation that the leaders of organisation X now have to face, what strategy should one adopt?' In some aspects, this perspective is very close to the 'pragmatic' perspective: in both, the researcher relates closely to the actor's actual situation, viewpoint, goals and practical problems. They differ, however, because the one studies the situation ex post (even if only one step behind) and the other, ex ante (even if only one step ahead). The trope 'the organisation is at the crossroads', which appears so often as one turns from analysing the past of an organisation to discussing perspectives for its future, expresses the contrast between the relative indeterminacy of the ex ante reflection on action, and the relative readability of the paths studied by ex post reflection.

The most important point is that the use of concepts differs profoundly between the ex ante or ex post perspectives. Management-as-design concepts - such as those we have presented here: the strategy-identity-aims-resources opponents nexus, the punctuation of strategic reasoning, the adversarial dimension of ENGO strategies, the environmental actor, the importance of activity sectors, and especially of the environmental sector-are not intended primarily for explaining and finely describing strategies ex post. When (mis)used in that perspective, they tend to appear clumsy, simplistic, and too obvious to be relevant. They are intended for heuristic ex ante reflection on action situations. They ask explicit questions that are simple in appearance, but that involve deeper conceptual research on strategy, and claim special relevance for ex ante strategic reflection. As ex ante reflection on strategy is a form of (or akin to) strategic design, it involves a different use of concepts than does ex post reflection on strategy, which is closer to description and explanation of facts and behaviour. 
However, if that difference of perspectives and style is clearly understood and accepted, then design-oriented forms of management research can be a useful complement to pragmatic sociological and historical studies of ENGO strategies, especially as, in order to draw lessons from the history of ENGOs, one looks for ways to switch back and forth between ex post and ex ante reflection.

\section{References}

Armsworth, P.R., et al. 2012. The size, concentration, and growth of biodiversity-conservation nonprofits. BioScience, 62 (3), 271-281. doi:10.1525/bio.2012.62.3.8

Benhammou, F. and Mermet, L., 2003. Stratégie et géopolitique de l'opposition à la conservation de la nature: le cas de l'ours des Pyrénées. Natures, Sciences, Sociétés, 11 (4), 381-394. doi:10.1016/j.natsci.2003.09.001

Berny, N., 2019. Défendre la cause de l'environnement en France. Une approche organisationnelle. Rennes, Presses Universitaires de Rennes. Forthcoming.

Billé, R., 2008. Integrated coastal zone management: four entrenched illusions. SAPIENS [online], 1 (2). $75-86$.

Boy, D., et al. 2012. Le Grenelle de l'environnement: acteurs, discours, effets. Paris: Armand Colin. Checkland, P., 1990. Soft systems methodology in action. Hoboken, NJ: John Wiley.

Crowley, J. and Ryan, M., 2013. Building a better international NGO: greater than the sum of the parts? Boulder, CO: Kumarian.

Crozier, M. and Friedberg, E., 1980. Actors and systems: the politics of collective action. Chicago: University of Chicago Press.

David, A., 2000. La recherche-intervention, cadre général pour la recherche en management? In: A. David, A. Hatchuel, and R. Laufer, eds. Les nouvelles fondations des sciences de gestion - éléments d'épistémologie de la recherche en management. Paris: FNEGE.

David, A., Hatchuel, A., and Laufer, R., eds., 2000. Les nouvelles fondations des sciences de gestion - éléments d'épistémologie de la recherche en management. Paris: FNEGE.

Dosse, F., 1998. Empire of meaning: the humanization of the social sciences. Minneapolis: University of Minnesota Press.

Emerit, A., 2007. Les aires protégées gérées. Zonage de l'espace et différenciation des rôles des acteurs: conditions d'une gestion intégrée des territoires. Le rôle des équipes des aires protégées alpines dans la gestion du retour du loup et dans la conservation du tétras-lyre. Thesis (PhD). Paris: AgroParisTech. 
Gamero, A., et al., 2016. Tracking progress towards EU biodiversity strategy targets: EU policy effects in preserving its common farmland birds. Conservation Letters [online]. doi:10.1111/conl.12292.

Guillet, F., 2011. Analyse stratégique pour les organisations à finalité environnementale. Le cas d'une ONGE, la Tour du Valat. Thesis (PhD)). Paris: Université de Cergy-Pontoise.

Guillet, F., et al. 2016. Effective action for biodiversity: a strategic framework for conservation nongovernmental organisations. Biodiversity and Conservation, 25 (9), 1711-1726. doi:10.1007/s10531-016-1153-3

Guillet, F. and Leménager, T., 2016. Fostering environmental integration in public aid: influence of interactions between environmental NGOs and aid donors, Voluntas [online]. doi:10.1007/s11266016-9720-5

Guillet, F. and Leroy, M., 2010. Perspective stratégique de la gouvernance d'une ONG de conservation de la nature. Politique Et Management Public, 27 (1), 11-30.

Hatch, M.J., 1997. Organization theory - modern, symbolic and postmodern perspectives. Oxford: Oxford University Press.

Latour, B., 2007. Reassembling the social: an introduction to actor-network-theory. Oxford: Oxford University Press.

Leroy, M., 2006. Gestion stratégique des écosystèmes du fleuve Sénégal: action et inaction publiques internationales. Paris: L'Harmattan.

Leroy, M. and Mermet, L., 2014. La gestion patrimoniale: innovations et limites de vingt-cinq ans de recherche d'une gestion concertée de l'environnement rural. In: L. Charles, H. Lange, B. Kalaora, and F. Rudolf., eds. Environnement et sciences sociales en France et en Allemagne. Paris: L'Harmattan, 389-410.

Leroy, M. and Mermet, L., 2012. Delivering on environmental commitments? Guidelines and evaluation framework for an "on-board” approach. Sécheresse, 23 (3), 185-195.

Mermet, L., 1992. Stratégies pour la gestion de l'environnement - La nature comme jeu de société?. Paris: L'Harmattan.

Mermet, L., et al., 2010. Concern-focused evaluation for ambiguous and conflicting policies: an approach from the environmental field. American Journal of Evaluation, 31, 180-198. doi:10.1177/1098214010366047

Mermet, L., 2011. Strategic environmental management analysis: addressing the blind spots of collaborative approaches. Pour Le Débat [online], 5, 31. (Paris: IDDRI-SciencesPo).

Mermet, L. and Leménager, T., eds., 2015. Development and biodiversity: navigating the environmental turning point. Paris: AFD - Collection Recherches. available online. 
Mintzberg, H., 1994. The fall and rise of strategic planning. Harvard Business Review, (JanuaryFebruary 1994), pp. 107-114.

Mintzberg, H., et al., 2003. The strategy process. 4th ed. New Jersey: Prentice Hall.

Mintzberg, H., Lampel, J., and Ahlstrand, B., 1998. Strategy safari - a guided tour through the wilds of strategic management. New York: The Free Press.

Pickerill, J., 2018. Green and black: the future of indigenous- environmental relations in Australia. Environmental Politics. doi:10.1080/09644016.2018.1466464

Raiffa, H., 1982. The art and science of negotiation - how to resolve conflicts and get the best out of bargaining. Cambridge, MA: Belknap - Harvard University Press.

Redford, K.H. and Taber, A., 2000. Writing the wrongs: developing a safe-fail culture in conservation. Conservation Biology, 14 (6), 1567-1568. doi:10.1046/j.1523-1739.2000.01461.x

Ricoeur, P., 1990. Time and narrative (3 volumes). Chicago: University of Chicago Press.

Rootes, C., 2013. From local conflict to national issue: when and how environmental campaigns succeed in transcending the local. Environmental Politics, 22 (1), 95-114. doi:10.1080/09644016.2013.755791

Rowell, A., 1996. Green backlash - global subversion of the environmental movement. London: Routledge.

Rumelt, R., 2011. Good strategy, bad strategy: the difference and why it matters. New York: Crown.

Sabatier, P.A. and Jenkins-Smith, H.C., eds., 1993. Policy change and learning - an advocacy coalition approach. Boulder, Co: Westview.

Taravella, R., 2008. La frontière pionnière amazonienne aujourd'hui: projet socioenvironnemental de conservation forestière contre dynamique pastorale de déforestation. Thesis ( $\mathrm{PhD})$. Paris: AgroParisTech

Thatcher, M., 1998. The development of policy network analyses: from modest origins to overarching frameworks. Journal of Theoretical Politics, 10 (4), 389-416. doi: $10.1177 / 0951692898010004002$

Watzlawick, J., Weakland, J.H., and Fisch, R., 1974. Change: principles of problem formation and problem resolution. New York: Norton.

Watzlawick, P., et al. 1967. Pragmatics of human communication: a study of interactional patterns, pathologies, and paradoxes. New York: Norton.

Whittington, R., 2007. Strategy practice and strategy process: family differences and the sociological eye. Organization Studies, 28(10), 1575-1586. 